\title{
mtDNA Diversity and Phylogenetic Analysis of Korean Native Goats
}

\author{
Jae-Hwan Kim*, Chang-Yeon Cho, Seong-Bok Choi, Young Moo Cho, Seung-Hum Yeon and Boh \\ Suk Yang
}

National Institute of Animal Science, R.D.A., Namwon 590-830, Korea

Received August 3, 2011 /Revised August 19, 2011 / Accepted August 22, 2011

\begin{abstract}
Korean native goats, which are characterized by black coat color, have existed on the Korean peninsula for a long time. Until now, there has been no comprehensive investigation concerning their genetic diversity, phylogenetic analysis or origin. In this study, we investigated the genetic diversity and verified phylogenetic status of the Korean native goat using the 453-bp fragment of the hypervariable fragment I (HVI) of mitochondrial DNA (mtDNA) D-loop region from 60 individuals among 5 populations. The Korean native goat showed less haplotype diversity when compared with goats from other countries. In addition, 6 haplotypes that had not been previously reported were verified in this study. In phylogenetic analyses with other country's goats, 10 haplotypes from Korean native goats were classified into $\mathrm{mtDNA}$ lineage A. Moreover, in a phylogenetic tree for goats which contained mtDNA lineage A, 8 of 10 haplotypes could be included in a subgroup with goats from Vietnam and an area of China. However, none of the remaining haplotypes belonged to a major group of Korean native goats and were located on different independent positions. These results suggest that almost Korean native goats aligned more closely to China and Vietnam breeds in mtDNA lineage A and there was no gene flow from other mtDNA lineages. Our results will contribute to conservation strategies and genetic breeding of Korean native goats.
\end{abstract}

Key words : Korean native goats, phylogenetic analysis, mtDNA, haplotype, lineage

\section{서 론}

가축화 염소(Capra hircus)는 전세계적으로 넓게 분포하고 있으며, 특히 중동, 아시아 및 아프리카의 여러 국가에서 고기, 우유, 털 및 가죽 등을 대상으로 유용하게 이용되고 있다 $[14,22]$. 또한 염소는 인류문명 초기부터 농경, 경제, 문화, 종교 등 여러 분야에서 인류문명과 밀접하게 연관되어 왔다[10].

염소의 기원, 가축화시기 및 유전적 이동경로 등을 해석하 기 위해서 현존하는 여러 가축화 품종들뿐만 아니라[1-2,7, 21,26], 유적지에서 출토된 고대유골을 이용한 고고학적 연구 들도 진행되었다[8,33]. Pringle [24], Zeder와 Hesse 등[33]은 약 1 만 년 전 서남아시아의 Fertile Crescent 지역에서 야생염 소인 bezoar (Capra aegagrus)로부터 처음으로 가축화가 시작 되었다고 보고하였다. 또한 이 지역과는 독립적으로 파키스탄 에서 가축화되었을 것으로 추정하는 연구보고들도 있어 $[17,22]$, 아직까지 염소의 가축화시기 및 기원에 대한 정확한 설명은 어려운 실정이다.

일반적으로 mitochondrial DNA (mtDNA) 혹은 microsatellite (MS) 마커를 이용하여 가축의 유전적 다양성 확인 및 계통유전학적 분석이 이루어지고 있다[5,6,9,15-16,31]. 특 히 $\mathrm{mtDNA}$ 는 모계유전양상을 보이며, $\mathrm{mtDNA}$ 내부의
D-loop 영역은 높은 염기변이율에 의한 풍부한 유전적 정보 를 가지고 있어 여러 가축을 대상으로 집단분석에 많이 이용 되고 있다[3,12,27,32]. 최근에 D-loop 영역을 토대로 보고된 여러 연구들은 가축화된 염소들이 다양한 모계혈통 $(\mathrm{A}, \mathrm{B}, \mathrm{C}$, $\mathrm{D}, \mathrm{F}, \mathrm{G})$ 을 나타내며, 또한 각 모계혈통별로 지리적-특이 분 포현상을 보인다고 보고하였다 $[7,11,13,18,28]$. 이런 결과들은 염소의 가축화 과정에서 다양한 모계혈통이 존재했거나 혹 은 처음 가축화가 발생한 후 다른 모계혈통의 유입 가능성을 제시하는 것이다.

최근 들어 재래가축 유전자원에 대한 주권이 국제적인 쟁점 으로 대두되면서 각국의 재래가축 유전자원의 보존에 많은 관심과 노력을 기울이기 있다. 특히 염소품종을 보유하고 있 는 국가들은 유전적 다양성 및 계통유전학적 분석결과를 보고 하고 있다[1-2,7,11,20-21,26,28]. 한국재래염소는 흑모색의 특 징을 나타내는 한반도의 유일한 염소 품종이지만, 현재까지 이들에 대한 계통유전학적 연구는 미비하며 보다 폭넓은 분석 이 필요한 실정이다.

따라서 본 연구에서는 한국재래염소의 분자유전학적 특성 평가의 토대를 마련하고 계통유전학적 위치를 구명하기 위하 여 mtDNA D-loop 영역의 서열을 토대로 유전적 특성 파악 및 타 품종들과의 계통유전학적 분석을 수행하였다.

\section{*Corresponding author}

Tel : +82-63-620-3522, Fax : +82-63-620-3590

E-mail : jkim3892@korea.kr 


\section{재료 및 방법}

\section{시료 수집 및 DNA 추출}

국립축산과학원 가축유전자원시험장에서 수집하여 보유중 인 4 개 집단(당진, 통영, 장수, 신안)과 농가 유래 1 개 집단(영 양) 등 총 5 개 한국재래염소 집단을 공시하였으며, 집단별로 12 두씩 전체 60 두에 대한 혈액시료를 채취한 후 $-70^{\circ} \mathrm{C}$ 에 보관 하였다. Genomic DNA는 sucrose-Proteinase K 방법[4]을 이 용하여 추출하였으며, NanoDrop ND1000 (Thermo Scientific, $\mathrm{USA})$ 을 이용하여 genomic DNA의 농도측정 후 $\mathrm{PCR}$ 증폭을 위한 주형을 제작하였다.

\section{PCR 증폭 및 D-loop 서열결정}

염소(Capra hircus) mtDNA 전체서열(NC_005044) 중 tRNA-Pro, D-loop 및 tRNA-Phe 영역의 서열을 이용하여 2쌍 의 primer를 서로 중복되게 제작하였다(Table 1). PCR 반응은 Taq polymerase 1.5 unit (TaKaRa, Japan), 10× buffer $2.5 \mu \mathrm{l}$, $0.2 \mathrm{mM} \mathrm{dNTP}, 1.5 \mathrm{mM} \mathrm{MgCl}$, 10 pmol primer 각각 $1.5 \mu \mathrm{l}$, genomic DNA $20 \mathrm{ng}$ 그리고 증류수를 첨가하여 최종 $25 \mu \mathrm{l}$ 로 반응하였다. PCR 증폭은 GeneAmp PCR system 9700 (ABI, $\mathrm{USA})$ 을 이용하여 $94^{\circ} \mathrm{C}$ 에서 5 분간 초기변성 후 $94^{\circ} \mathrm{C}$ 에서 30 초, $65^{\circ} \mathrm{C}$ 에서 30 초, $72^{\circ} \mathrm{C}$ 에서 60 초 1 회로 하여 35 회 반복수행 하였 으며, $72^{\circ} \mathrm{C}$ 에서 5 분간 최종 신장하였다. $\mathrm{PCR}$ 증폭산물은 $1.5 \%$ agarose 전기영동 상에서 최종 확인한 후 QIAEX II Gel
Extraction Kit (Quagen, USA)로 정제하였다. 염기서열 분석 은 ABI 3130 DNA Genetic Analyzer (ABI, USA) 기기를 이용 하여 direct-sequencing을 수행하였다. 분석서열은 염소(Capra hircus) mtDNA 전체서열(NC_005044)을 이용하여 D-loop 영 역 앞뒤 경계지역을 확인하여 결정하였으며, GenBank database에 등록하였다(JN366377-98).

\section{$\mathrm{mtDNA}$ 유전특성 및 계통유전학적 분석}

한국재래염소와의 계통유전학적 분석을 위해서 GenBank database에 등록되어 있는 60 개의 HVI 서열을 수집하여 분석 에 이용하였다(Table 4). D-loop 전체서열 및 HVI 서열의 다중 염기정렬은 CRUSTAL W 프로그램[30]을 이용하였으며, 변이 부위 탐색, 유전적 변이성 추정 및 haplotype의 결정은 DNA Sequence Polymorphism (Ver. 5.1)을 사용하였다. 한국재래 염소의 모계혈통을 확인하기 위한 유전적 거리지수 추정 및 계통도 작성은 PHYLIP v3.6b 프로그램을 사용하였으며, 이 때 Kimura 2-parameter model을 적용한 Dnadist 프로그램으 로 거리지수 산출 후 Neighbor-joining tree를 작성하였다. 또 한 한국재래염소가 속하는 모계혈통 내 서열들과의 계통분석 을 위한 최적모델 설정은 MrModeltest $2.3[19,23]$ 을 수행한 후 PAUP 4.0 [29]에서 분석하였다. 계통수 작성은 MRBAYES 3.1 [25]을 이용해 16,000,000번 반복수행 후 FigTree ver. 1.3.1 을 이용하여 도식화 하였다.

Table 1. The primer sequences for amplification of the mtDNA D-loop region used in this study

\begin{tabular}{ccc}
\hline \multirow{2}{*}{ Target } & \multicolumn{2}{c}{ Primer sequence $\left(5^{\prime}--3^{\prime}\right)$} \\
\cline { 2 - 3 } & \multicolumn{1}{c}{ Forward } & \multicolumn{1}{c}{ Reverse } \\
\hline D-loop-1 & TATCAGCACCCAAAGCTGAA & GTGAGATGGCCCTGAAGAAA \\
D-loop-2 & GATCACGAGCTTGTTGACCA & GCATTTTCAGTGCCTTGCTT \\
\hline
\end{tabular}

Table 2. Genetic diversity among 5 populations based on complete and HVI regions of the D-loop region

\begin{tabular}{ccccccc}
\hline \multirow{2}{*}{ Region } & Population $^{1}$ & Sample size & $\begin{array}{c}\text { Number of } \\
\text { polymorphic sites }\end{array}$ & $\begin{array}{c}\text { Number of } \\
\text { haplotypes }\end{array}$ & $\begin{array}{c}\text { Haplotype } \\
\text { diversity }\end{array}$ & $\begin{array}{c}\text { Nucleotide } \\
\text { diversity }\end{array}$ \\
\hline Complete & $\mathrm{Da}$ & 12 & 12 & 5 & 0.8030 & 0.0028 \\
& $\mathrm{Ja}$ & 12 & 12 & 4 & 0.7424 & 0.0032 \\
& $\mathrm{To}$ & 12 & 15 & 4 & 0.7121 & 0.0029 \\
& $\mathrm{Ye}$ & 12 & 7 & 5 & 0.7879 & 0.0016 \\
& $\mathrm{Si}$ & 12 & 6 & 5 & 0.6667 & 0.0021 \\
& Total & 60 & 24 & 12 & 0.8153 & 0.0027 \\
\hline $\mathrm{HVI}$ & $\mathrm{Da}$ & 12 & 11 & 3 & 0.5909 & 0.0048 \\
& $\mathrm{Ja}$ & 12 & 14 & 4 & 0.7424 & 0.0079 \\
& $\mathrm{To}$ & 12 & 6 & 5 & 0.7121 & 0.0062 \\
& $\mathrm{Ye}$ & 12 & 5 & 5 & 0.7879 & 0.0038 \\
& $\mathrm{Si}$ & 12 & 20 & 10 & 0.6667 & 0.0044 \\
& Total & 60 & & 5 & 0.7802 & 0.0058 \\
\hline
\end{tabular}

${ }^{1}$ Aliases for population names of Korean native goats used in this study. Da: Dangin, Ja: Jangsu, To: Tongyeong, Ye: Yeongyang, and Si: Shinan. 


\section{결과 및 고찰}

본 연구에서는 한국재래염소 5 개 집단, 60 두를 대상으로 mtDNA D-loop 영역의 전체 염기서열을 결정하였다. 결정된
염기서열을 이용하여 D-loop 전체영역(1,212 bp 혹은 1,213 bp)과 HVI (hypervariable fragment I) 영역(453 bp)을 이용하 여 유전적 다양성 분석을 실시하였다(Table 1). D-loop 전체영 역에서 24 개의 염기치환변이와 1 개의 삽입/결실변이가 확인

Table 3. Distribution of mtDNA HVI haplotypes in 5 goat populations and comparison with a previous report

\begin{tabular}{|c|c|c|c|c|c|c|c|}
\hline \multirow{2}{*}{ Haplotype } & \multicolumn{5}{|c|}{ Populations } & \multirow{2}{*}{ Total } & \multirow{2}{*}{$\begin{array}{l}\text { Odahara et } \\
\text { al. [20] }\end{array}$} \\
\hline & $\mathrm{Da}$ & $\mathrm{Ja}$ & To & Ye & $\mathrm{Si}$ & & \\
\hline hap_1 & 7 & 5 & 6 & 5 & 1 & 24 & 1 \\
\hline hap_2 & 1 & 2 & & & & 3 & 1 \\
\hline hap_3 & 4 & & & & 7 & 11 & \\
\hline hap_4 & & 4 & 2 & 3 & 1 & 10 & 1 \\
\hline hap_5 & & 1 & & & 2 & 3 & 1 \\
\hline hap_6 & & & 1 & & & 1 & \\
\hline hap_7 & & & 3 & & 1 & 4 & \\
\hline hap_8 & & & & 2 & & 2 & \\
\hline hap_9 & & & & 1 & & 1 & \\
\hline hap_10 & & & & 1 & & 1 & \\
\hline hap_11 & & & & & & & 1 \\
\hline hap_12 & & & & & & & 1 \\
\hline
\end{tabular}

Table 4. Information on reference sequences for comparison with Korean native goats

\begin{tabular}{|c|c|c|c|}
\hline Regions & Countries & $\begin{array}{c}\text { Number of } \\
\text { sequences }\end{array}$ & Accession numbers \\
\hline \multirow[t]{6}{*}{ Eastern Asia } & Bhutan & 2 & AJ317851, AJ317855 \\
\hline & Laos & 3 & AB044295, АB044300, АB044303 \\
\hline & China & 10 & $\begin{array}{l}\text { AJ317569, DQ089106, DQ089135, AY853278, DQ121491, AY188849, } \\
\text { AY860871, DQ121578, DQ188892, DQ188893 }\end{array}$ \\
\hline & Malaysia & 2 & AJ317553, AJ317828 \\
\hline & Mongolia & 3 & AJ317534, AJ317833, EF618234 \\
\hline & Vietnam & 2 & AJ317566, EF618541 \\
\hline \multirow{6}{*}{ Middle East } & Iran & 4 & EF617863, EF618084, EF617945, EF617965 \\
\hline & Jordan & 3 & AJ317769, EF618191, EF618200 \\
\hline & Pakistan & 2 & AJ317533, AB110552 \\
\hline & Saudi Arabia & 2 & AJ317752, EF618309 \\
\hline & Syria & 2 & AJ317760, AJ317761 \\
\hline & Turkey & 3 & AJ317736, EF618492, EF618535 \\
\hline \multirow[t]{3}{*}{ Western Asia } & Azerbaijan & 2 & EF617702, EF617706 \\
\hline & Dagestan & 2 & EF617708, EF617709 \\
\hline & India & 6 & AJ317827, AJ317856, AJ317560, AY155721, AY155708, AY155952 \\
\hline \multirow[t]{2}{*}{ Northern Africa } & Egypt & 4 & AJ317780, AJ317795, EF617711, EF617727 \\
\hline & Nigeria & 2 & AJ317810, EF618246 \\
\hline \multirow[t]{6}{*}{ Northern Europe } & Austria & 2 & EF617678, EF617701 \\
\hline & France & 3 & AJ317575, AJ317723, EF617779 \\
\hline & Germany & 3 & AJ317586, AJ317649, EF617788 \\
\hline & Iceland & 2 & AJ317587, EF617851 \\
\hline & Poland & 2 & AJ317584, EF618264 \\
\hline & Switzerland & 4 & AJ317838, AJ317573, AJ317619, EF618423 \\
\hline \multirow[t]{3}{*}{ Southern Europe } & Italy & 3 & EF618134, AJ317674, AJ317685 \\
\hline & Sicily & 3 & DQ241349, DQ241351，DQ241370 \\
\hline & Spain & 4 & AJ317625, AJ317703, AJ317709, EF618413, \\
\hline Total & & 80 & \\
\hline
\end{tabular}


되었다. 염기치환은 transversion 변이 없이 모두 transition 변이로 확인되었다. 삽입결실변이는 기존에 보고된 염소 D-loop 서열(AY853278)을 기준으로 1074번째(C)와 1075번째 (T) 사이에 한 개의 C 염기가 삽입/결실되는 현상으로서 본 연구의 분석에는 포함시키지 않았다. 통영집단에서 가장 많은 15 개의 염기변이가 확인되었으며, 신안 집단에서 가장 적은 6개 염기변이가 나타났다. 반면에 HVI 영역에서는 전체 20개 의 염기변이 $(83 \%)$ 가 확인되었고, 약 2 배 이상의 nucleotide 다 양성지수 $(0.0058)$ 를 보였다. 이는 기존에 여러 보고들에 의한 D-loop 영역 중 HVI 영역이 고도의 염기변이 영역임을 재확 인하였다. 집단별 nucleotide 다양성지수에서 장수집단 $(0.0032,0.0079)$ 이 D-loop 전체 및 HVI 영역 모두에서 가장 높게 나타났으며, 영양집단 $(0.0016,0.0038)$ 이 가장 낮게 나타 났다. Haplotype 다양성지수는 당진집단이 D-loop 전체영역 인 경우 가장 높은 0.8030 을 나타낸 반면, HVI 영역인 경우 0.5909 로 가장 낮게 나타났다. 이는 당진집단에서 나타난 염기 변이 중 HVI 영역이 아닌 다른 D-loop 영역에서 2개의 염기변 이가 확인되었으며, 이로 인해 HVI 영역에서 2개의 haplotype 이 감소된 원인으로 판단된다. 나머지 집단의 haplotype 수 및 다양성지수는 두 영역에서 동일하게 나타났다. HVI에서 나타난 평균 haplotype 다양성지수가 0.7802 로서, 기존에 보고 된 모계혈통별, 국가별 가축화 염소들에 비해서 상대적으로 낮게 나타났다[18]. 본 결과를 바탕으로 한국재래염소가 하나 의 품종으로 과거 오랜 기간 동안 우리나라에서 사육되어 오 면서 품종 내 교배가 이루어졌고, 또한 외부 유전자 유입이 상대적으로 적었을 것으로 추정된다.

HIV 영역에서 확인된 20개 염기변이를 토대로 10개 haplotype으로 분류되었으며, 전체 60 두 중 45 두 $(75 \%)$ 가 3 개의 haplotype (hap_1, 3, 4)에 분포하는 것으로 조사되었다(Table 3). hap_1에는 당진집단 7 두, 장수집단 5 두, 통영집단 6 두, 영 양집단 5 두 그리고 신안집단 1 두 등 모든 집단으로부터 가장 많은 24 두가 속하였고, 신안집단을 제외한 나머지 집단들의 $40 \%$ 이상의 개체들이 포함되었다. hap_4에는 당진집단을 제 외한 나머지 집단들로 구성되었고, hap_3인 경우 $58 \%$ 의 신안 집단과 $33 \%$ 의 당진집단만이 포함되었다. 4 개의 집단-특이 haplotype이 나타났는데, hap_6은 통영집단 1두, hap_8 10은 영양집단 각각 $2,1,1$ 두가 속하였다. Odahara 등[20]에 의해 보고된 한국재래염소의 6 개 haplotype 중 4 개는 본 연구에서 도 확인되었으나 나머지 2개는 확인되지 않았다. 반면에 본 연구에서 아직 보고되지 않는 6개의 새로운 haplotype이 통영, 영양, 신안집단에서 확인되었다(Table 3). 이런 결과는 한국재 래염소의 새로운 haplotype이 더 존재할 가능성을 제시하는 것으로서, 추가 지역을 대상으로 더 많은 개체들에 대한 분석 이 필요할 것으로 판단된다.

HVI 영역은 D-loop 영역 중 높은 염기변이율을 나타내며, 이 영역을 이용한 가축화 염소의 연구결과들에 의하면 여러
모계혈통 및 각 혈통들에 대한 서열이 보고되어 있다. 따라서 타 품종들과의 계통유전학적 분석을 통한 한국재래염소의 모 계혈통을 확인하기 위해서 80개의 HVI 영역에 대한 서열을 수집하였다(Table 4). 한국재래염소 및 수집된 HVI 서열을 이 용하여 neighbor-joining tree를 작성하였다(Fig. 1). 전체 6개 의 모계혈통(A, B, C, D, F, G)으로 분류되었으며, 본 연구에서 공시한 한국재래염소 5 집단 60 개체 모두 $\mathrm{A}$ 모계혈통에 속하 였다. A 모계혈통 내에서 한국재래염소의 10개 haplotype에 대한 계통유전학적 위치를 확인하기 위해서 A 모계혈통에 속 하는 타 품종들을 대상으로 MRBAYES 3.1을 이용한 consensus tree를 작성하였다(Fig. 2). 한국재래염소 8개 haplotype은 베트남 염소 및 분석에 사용한 일부 중국염소와 같은 subgroup을 형성하였다. 반면에 hap_2와 hap_6은 각각 서로 독립적으로 존재하였다. hap_2는 Odahara 등[20]에 의해 보고

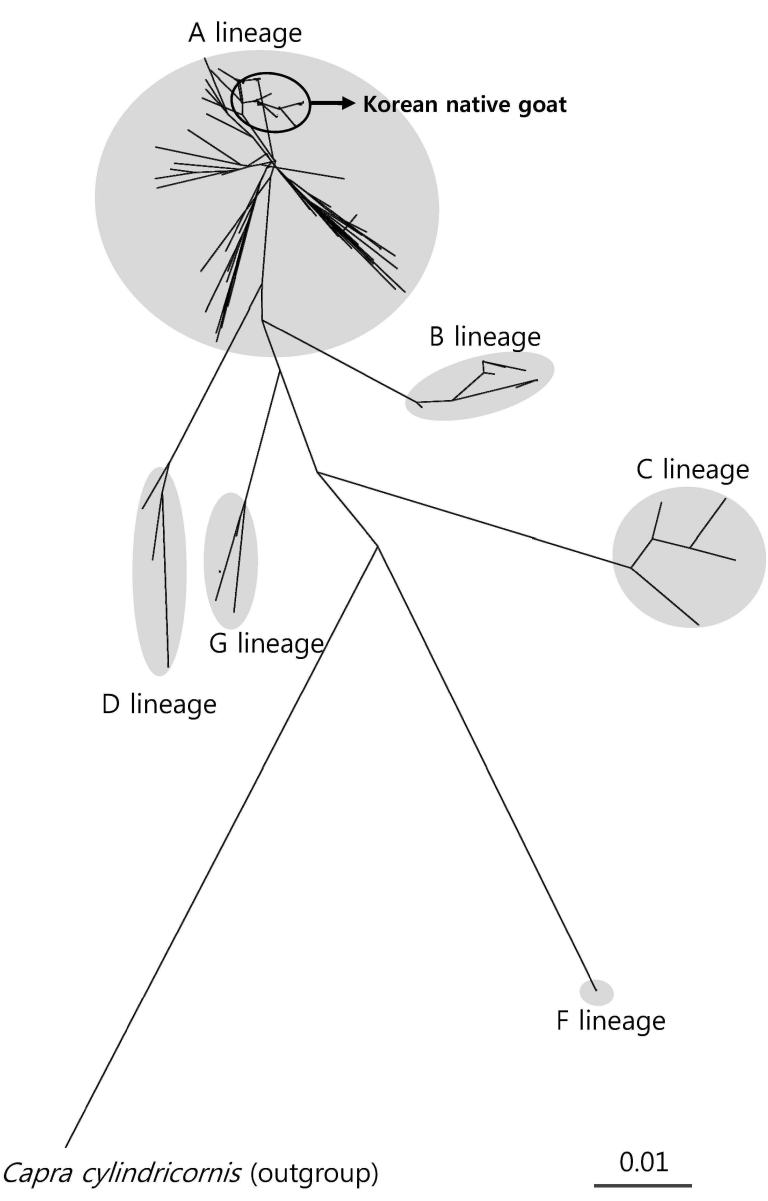

Fig. 1. A neighbor-joining tree of domestic goats (Capra hircus) based on HVI sequences of mtDNA D-loop region. 60 Korean native goats and 80 reference sequences were used for construction of this tree. Distances were calculated using the Kimura 2-parameter model. Six mtDNA lineages (A, B, C, D, F, and G) formed, and the Korean native goats were classified into mtDNA lineage $A$. Capra cylindricornis (AJ317870) was used as an outgroup. 


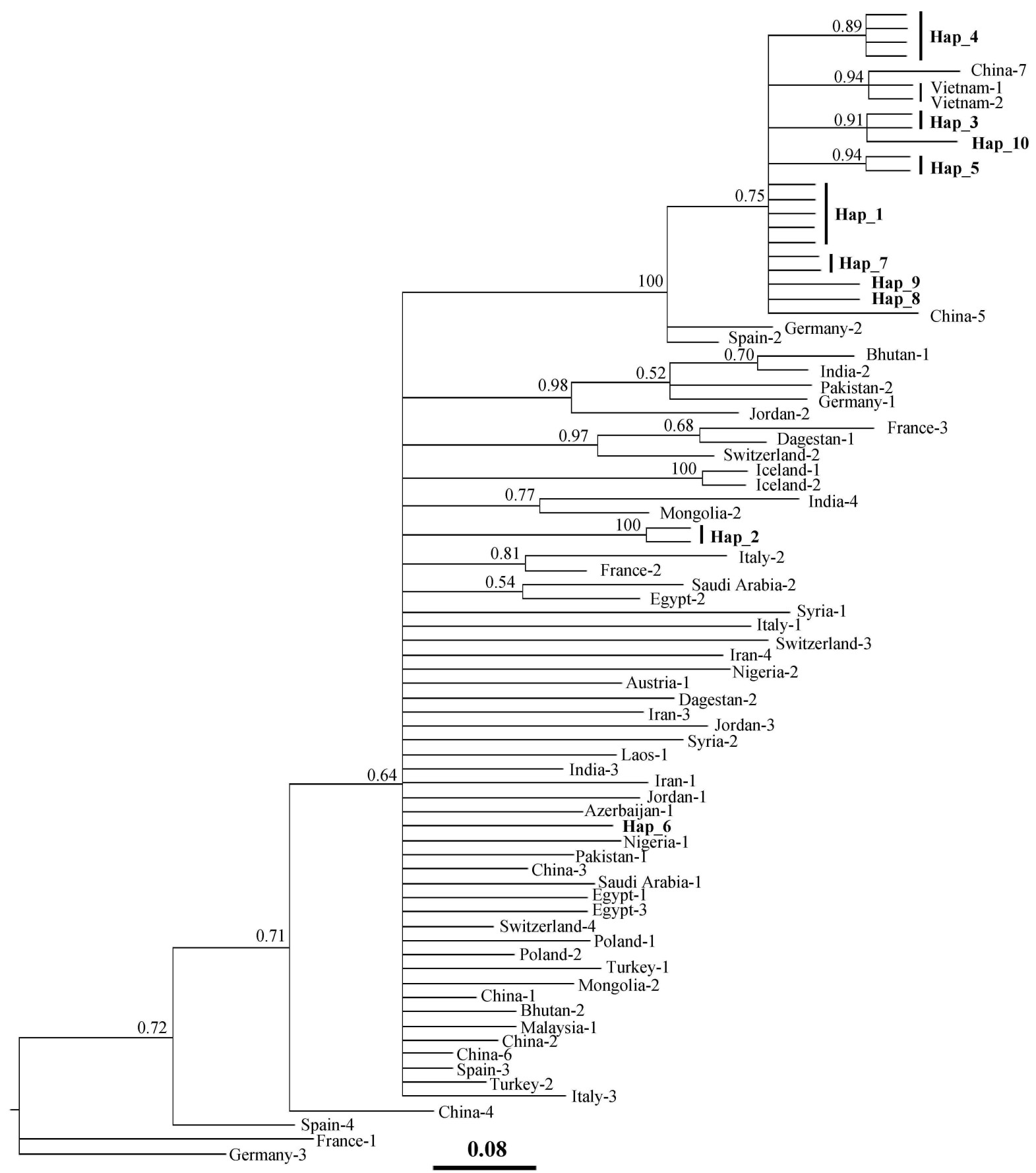

Fig. 2. A consensus phylogenetic tree reconstructed using statistics for the taxon bipartitions and clade credibility (posterior probability) values. The Bayesian Markov chain Monte Carlo analysis was run with the Hasegawa-Kishino-Yano (HKY) [10] model. The average standard deviation of split frequencies reached 0.008436 after 16 million iterations.

된 반면 hap_6은 보고되지 않은 것으로서, 한국재래염소 내에 서 분포율은 적지만 독립적인 계통유전학적 위치를 나타내는 새로운 haplotype이 존재할 가능성을 제시해주고 있다.

본 연구는 한국재래염소를 대상으로 mtDNA D-loop 영역 내 $\mathrm{HVI}$ 서열을 토대로 유전적 다양성 및 계통유전학적 분석을
실시하였다. Haplotype 다양성지수가 다른 국가단위 염소들 에 비해서 낮게 나타나 외부로부터 유전자 유입이 아직까지는 적은 것으로 판단된다. 또한 계통유전학적 분석에서 기존보고 $[18,20]$ 와 동일하게 A 모계혈통에 속하는 것으로 나타났으나, 본 연구에서 상대적으로 많은 집단 및 개체를 공시하였고, 6 개 
의 새로운 haplotype이 확인되어 조금 더 명확한 한국재래염 소의 유전적 특성을 구명하였다. 본 연구의 결과는 우리나라 가축유전자원으로서 한국재래염소의 보존 및 유전육종 방안 의 수립을 위한 기초 자료로서, 추후 한국재래염소의 고유성 을 인정할 수 있는 과학적 근거로 사용이 가능할 것이다. 하지 만 새로운 haplotype의 발견과 더불어 최근 들어 재래종의 낮은 생산성을 향상시키기 위한 외래종의 도입[12] 등이 발생 하고 있어, 한국재래염소의 더욱 명확한 분석 및 고유의 유전 형질 보존을 위해서는 우리나라 전 지역 및 다른 품종들을 수집하고 핵 DNA에 존재하는 MS 마커를 이용한 추가 분석이 이루어져야 할 것으로 사료된다.

\section{감사의 글}

본 연구는 농촌진흥청 연구개발사업 어젠다(2-5-12) 과제 (과제번호: PJ006757) 지원에 의한 연구결과의 일부임.

\section{References}

1. Amills, M., J. Capote, A. Tomas, L. Kelly, G. Obexer-Ruff, A. Angiolillo, and A. Sanchez. 2004. Strong phylogeographic relationships among three goat breeds from the Canary Islands. J. Dairy Res. 71, 257-262.

2. Azor, P. J., L. V. Monteagudo, M. Leque, M. T. Tejedor, E. Rodero, I. Sierra, M. Herrera, A. Rodero, and M. V. Arruge. 2005. Phylogenetic relationships among spanish goats breeds. Anim Genet. 35, 423-425.

3. Beja-Pereira, A., P. R. England, N. Ferrand, S. Jordan, A. O. Bakhiet, M. A. Abdalla, M. Mashkour, J. Jordana, P. Taberlet, and G. Luikart. 2004. African origins of the domestic donkey. Science 304, 1781.

4. Birren, B., E. D. Green, S. Klapholz, R. M. Myers, and J. Roskams. 1997. Genome analysis: A Laboratory Manual (USA: Cold Spring Harbor Laboratory Press).

5. Bjørnstad, G., N. Ø. Nilsen, and K. H. Røed. 2003. Genetic relationship between Mongolian and Norwegian horses?. Anim Genet. 34, 55-58.

6. Chang, W. H., H. P. Chu, Y. N. Jiang, S. H. Li, Y. Wnag, C. H. Chen, K. J. Chen, C. Y. Lin, and Y. T. Ju. 2009. Genetic variation and phylogenetic of Lanyu and exotic pig breeds in Taiwan analyzed by nineteen microsatellite markers. $J$. Anim Sci. 87, 1-8.

7. Chen, S. Y., Y. H. Su, S. F. Wu, T. Sha, and Y. P. Zhang. 2005. Mitochondrial diversity and phylogeographic structure of Chinese domestic goats. Mol. Phylogenet. Evol. 37, 804-814.

8. Fernández, H., S. Hughes, J. D. Vigne, D. Helmer, G. Hodgins, C. Miqual, C. Hänni, G. Luikart, and P. Taberlet. 2006. Divergent mtDNA lineages of goats in an Early Neolithic site, far from the initial domestication areas. Proc. Natl. Acad Sci. USA 103, 15375-15379.

9. Hiendleder, S., B. Kaupe, R. Wassmuth, and A. Janke. 2002.
Molecular analysis of wild and domestic sheep questions current nomenclature and provides evidence for domestication from two different subspecies. Proc. R. Soc. Lond B 269, 893-904.

10. Hasegawa, M., K. Kishino, and T. Yano. 1985. Dating the human-ape splitting by a molecular clock of mitochondrial DNA. J. Mol. Evol. 22, 160-174.

11. Joshi, M. B., P. K. Rout, A. K. Mandal, C. Tyler-Smith, L. Singh, and K. Thangaraj. 2004. Phylogeography and origin of Indian domestic goats. Mol. Biol. Evol. 21, 454-462.

12. Kim, Y. K., J. W. Lee, S. H. Choi, S. K. Son, K. J. Na, S. J. Moon, and J. H. Kim. 2002. Parameter estimates for genetic effects on growth traits of Korean native goats. J. Anim Sci. Technol. 44, 171-180.

13. Luikart, G., L. Giellly, L. Excoffier, J. D. Vigne, J. Bouuvet, and P. Taberlet. 2001. Multiple maternal origins and weak phylogeographic structure in domestic goats. Proc. Natl. Acad Sci. USA 98, 5927-5932.

14. MacHugh, D. E. and D. G. Bradley. 2001. Livestock genetic origins: goats buck the trend. Proc. Natl. Acad Sci. USA 98, 5382-5384.

15. Mannen, H., Y. Nagata, and S. Tsuji. 2001. Mitochondrial DNA reveal that domestic goat (Capra hircus) are genetically affected by two subspecies of bezoar (Capra aegagurus). Biochem Genet. 39, 145-154.

16. Martin-Burríel, I, C. Rodellar, J. A. Lenstra, A. Sanz, C. Cons, R. Osta, M. Reta, S. D. Argüello, A. Sanz, and P. Zaragoza. 2007. Genetic diversity and relationships of endangered Spanish cattle breeds. J. Hered 98, 687-691.

17. Meadow, R. H. 1993. Animal domestication in the Middle East: a revised view from the eastern margin. In Possehl, G. L. (ed.), pp. 259-320, Harappan Civilization. Oxford and IBH, New Delhi.

18. Naderi, S., H. R. Rezaei, P. Taberlet, S. Zundel, S. A. Rafat, H. R. Naghash, M. A. A. El-Barody, O. Ertugrul, and F. Pompanon. 2007. Large-scale mitochondrial DNA analysis of the domestic goat reveals six haplogroups with high diversity. PLOS ONE 10, e1012.

19. Nylander, J. A. A. 2004. MrModeltest v2. Program distributed by the author. Evolutionary Biology Centre, Uppsala University. (http://darwin.uvigo.es/software/modeltest.html)

20. Odahara, S., H. J. Chung, S. H. Choi, S. L. Yu, S. Sasazaki, H. Mannen, C. S. Park, and J. H. Lee. 2005. Mitochondrial DNA diversity of Korean native goats. J. Anim Science 19, 482-485.

21. Pereira, F., L. Pereira, B. Van Asch, D. Bradley, and A. Amorim. 2005. The mtDNA catalogue of all Portuguese autochthonous goat (Capra hircus) breeds: high diversity of female lineages at the western fringe of European distribution. Mol. Ecol. 14, 2313-2318.

22. Porter, V. 1996. Goats of the world. Farming Press, Ipswich, UK.

23. Posada, D. and K. A. Crandall. 2001. Selecting the best-fit model of nucleotide substitution. Syst. Biol. 50, 580-601.

24. Pringle, H. 1998. Neolithic agriculture: reading the signs of 
ancient animal domestication. Science 282, 1448.

25. Ronquist, F. and J. P. Huelsenbeck. 2003. Mrbayes 3: Bayesian phylogenetic inference under mixed models. Bioinformatics 19, 1572-1574.

26. Sardina, M. T., M. Ballester, J. Marmi, R. Finocchiaro, and J. B. van Kaam. 2006. Phylogenetic analysis of Sicilian goats reveals a new mtDNA lineage. Anim Genet. 34, 376-378.

27. Savolainen, P., Y. P. Zhang, J. Luo, J. Lundeberg, and T. Leitner. 2002. Genetic evidence for an East Asian origin of domestic dogs. Science 298, 1610-1613.

28. Sultana, S., H. Mannen, and S. Tsuji. 2003. Mitochondrial DNA diversity of Pakistani goats. Anim Genet. 34, 417-421.

29. Swofford, D. L. 2003. PAUP*. Phylogenetic analysis using parsimony (*and other methods), Version 4. Sinauer Associates.

30. Thompson, J. D., D. G. Higgins, and T. I. Gibson. 1994.
CLUSTAL W: improving the sensitivity of progressive multiple sequence alignment through sequence weighting, position-specific gap penalties and weight matrix choice. Nucl. Acids Res. 22, 4673-4680.

31. Troy, C. S., D. E. MacHugh, J. F. Bailey, D. A. Magee, R. T. Loftus, P. Cunningham, A. T. Chamberlain, B. C. Sykes, and D. G. Bradley. 2001. Genetic evidence for Near-Eastern origins of European cattle. Nature 410, 1088-1091.

32. Vilà, C., J. A. Leonard, A. Götherström, S. Marklund, K. Sandberg, K. Liden, R. K. Wayne, and H. Ellegern. 2001. Widespread origins of domestic horse lineages. Science 291, 474-477.

33. Zeder, M. A. and B. Hesse. 2000. The initial domestication of goats (Capra hircus) in the Zagros Mountain 10,000 years ago. Science 287, 2254-2257.

\section{초록 : 한국재래염소의 mtDNA 다양성 및 계통유전학적 분석 \\ 김재환^· 조창연 · 최성복· 조영무 · 연성흠·양보석 \\ (농촌진흥청 국립축산과학원)}

한국재래염소는 흑모색의 특징을 나타내며, 유일한 염소 품종으로서 오랫동안 한반도에서 사육되어 왔다. 하 지만 이들에 대한 유전적 다양성, 계통유전학적 분석 등을 통한 기원 추정 등에 대한 연구는 미비한 실정이다. 본 연구에서 한국재래염소 5 개 집단, 60 두를 대상으로 $\mathrm{mtDNA}$ D-loop 영역 중 HVI 영역의 서열을 이용하여 유 전적 다양성 및 계통유전학적 분석을 실시하였다. 한국재래염소는 다른 나라 염소들에 비해서 haplotype 다양성 지수가 낮게 나타났다. 또한 본 연구에서 분류된 한국재래염소 10 개 haplotype 중 현재까지 보고되지 않은 6개의 새로운 haplotype이 확인되었다. 계통유전학적 분석 결과, 분석에 사용된 모든 한국재래염소는 mtDNA 모계혈통 $\mathrm{A}$ 에 속하였다. 10개의 haplotype 중 8개는 베트남, 일부 중국 염소와 함께 subgroup을 형성하였다. 그러나 나머 지 2개 haplotype은 각각 서로 독립적인 계통유전학적 위치를 보였다. 이런 결과들을 토대로 한국재래염소는 상 대적으로 높은 근친상황으로 외부 유전자 유입이 적었을 것이라고 추정된다. 한국재래염소의 새로운 mtDNA haplotype의 발견 및 유전자원 보존 및 평가를 위해서 더 많은 분석집단 및 개체를 수집하고, MS 마커를 이용한 추가분석이 필요하다고 사료된다. 